\title{
Growth, Yield and Proximate Composition of Groundnut (Arachis hypogaea L.) as Influenced by Land Preparation Methods
}

\author{
Bolaji Umar OLAYINKA*, Bilqis Temitope YUSUF, Emmanuel Obukohwo ETEJERE \\ University ofIlorin, Department of Plant Biology, P.M.B 1515, Ilorin, \\ Nigeria;Olayinkabu@unilorin.edu.ng(*orrespondingauthor);biyusuf@yahoo.com; eotejere@yahoo.com
}

\begin{abstract}
Field experiments were carried between May and July 2014 to investigate the effects of three land preparation methods (flat surface, raised beds and ridges) on growth, yield and proximate composition of groundnut. The plots layout followed complete randomized block design with three replications. The results showed that growth parameters such as plant height, number of primary branches and leaf area were the highest in raised beds, followed by ridges and flat surface. Yield components such as number of matured pods per plant, number of seeds per plant and seed weight per plant were significantly higher in raised beds compared to other planting methods. Higher pod and seed yield were recorded under raised beds, but these were not statistically different from those of ridges. Regardless of the planting method, the percentage moisture, ash, fibre crude protein, crude fat and carbohydrate had values that ranged between $11.30 \pm 0.88-10.67 \pm 0.61 \%, 2.38 \pm$ $0.33-2.07 \pm 0.20 \%, 4.97 \pm 0.05-9.95 \pm 0.19 \%, 23.84 \pm 0.1426 .51 \pm 0.20 \%$, $44.17 \pm 0.37-48.86 \pm 0.47 \%$ and $5.89 \pm 0.149 .59 \pm 0.19 \%$ respectively. However, raised beds planting method had a remarkable influence on ash, fiber and crude protein, but limit the fat and carbohydrates contents of the seeds when compared to other planting methods. In view of its influence on growth, yield and some aspects of proximate composition, raised beds method of planting is therefore suitable for producing Arachis hypogaea L., 'MK 373 ' cultivar of groundnut.
\end{abstract}

Keywords: ash, crude fibre, crude protein, cultivation methods, yield

\section{Introduction}

Groundnut (Arachis hypogaea L.) is one of the major oil seed crops in the world. China, India, United States of America (USA) and Nigeria are the main producers of groundnut to the rest of the world (Campos-Mondragón et al., 2009). In Nigeria, groundnut has various uses such as vegetable cooking oil, livestock feeds and groundnut cake (Kulikuli' in Yoruba and Nupe). It is also a major snacks food that goes well with cassava flakes (Hamidu et al., 2006; Obi et al., 2008). Groundnut seed contains $44-56 \%$ oil and $22-30 \%$ protein on a dry seed basis and is a rich source of mineral (phosphorus, calcium, magnesium and potassium) and vitamins (E, K and B group) (Savage and Keenan, 1994). Different land preparation methods are practiced worldwide at the time of sowing different crops. Ridge tillage can be considered as an alternative to no-tillage in climates and environments which are not very favorable for the latter (Liu and Yong, 2008). Abdullah et al. (2008) reported that ridge planting significantly increased yield of maize when compared with other methods. Conventional flat bed planting for winter maize has some disadvantages. Govaerts et al. (2004), Wang et al. (2004) and Ortega et al. (2008) reported that raised bed planting is the most efficient method for wheat, maize and other crops. Methods of land preparation have also been found to affect water use efficiency through improved root development, resulting in better crop growth and productivity. It should be noted that land preparation methods have been practiced in cereals crop such as wheat, maize, rice as reviewed in the foregoing literatures. However, information on the effect of land preparation methods on growth, yield and proximate composition of leguminous crops groundnut to be precise is very scanty. The present investigation was therefore carried out keeping in view the crucial role that methods of land preparation play for improving crop yield.

\section{Materials and methods}

\section{Study site}

The present investigation was carried out at the Botanical Garden of University of Ilorin, Nigeria. The experimental field was made on loamy sand soil with very high organic carbon (2.16\%) and organic matter $(3.74 \%)$. The available phosphorus $(0.0219 \mathrm{ppm})$ and total nitrogen of $0.03 \%$ were very low with strongly alkaline $\mathrm{pH}$ (8.6). The rainfall received during the cropping season between May and July 2014 was $495.5 \mathrm{~mm}$.

\section{Seeds collection and description}

The variety of the groundnut seeds used for this study was MK 373. They were obtained from the Department of Agriculture Lafiagi in Edu Local Government Area of Kwara 
228

State. The pods were long containing an average of three seeds each. Seeds were brown in colour and matured between $85-90$ days. Growth habit was decumbent, meaning the lower parts of the branches lie close to the ground, with main stem growing upward.

\section{Experimental layout and treatment details}

The field layout followed completely randomized block design with three replications. The gross plot size was $10 \times 7 \mathrm{~m}$. There were six sub plots, each measuring $3 \times 3 \mathrm{~m}$, separated by a $0.5 \mathrm{~m}$ alley. The treatments consisted of three land preparation methods. These are flat beds, raised bed and ridges. In all methods, within row spacing was $0.3 \mathrm{~m}$, while between rows was $0.5 \mathrm{~m}$. Data on crop were collected from the two inner rows leaving the other row as buffer.

\section{Field planting}

The field was manually cleared using cutlass to remove the grasses and stumps. The plot was marked out using tape rule graduated in meter. The three planting methods (flat beds, raised beds and ridges were made using hoe). Healthy groundnut seeds were selected for sowing on $3^{\text {rd }}$ May, 2014. Two seeds were sown per hole at a depth of $0.03 \mathrm{~m}$ with in row spacing of $0.3 \mathrm{~m}$. Prior to planting, seeds were treated with seedrex $(33 \%$ permethrin + $15 \%$ carbonderzine $+12 \%$ chlorothalonil) at a rate of $4 \mathrm{~kg}$ of seeds $/ 10 \mathrm{~g}$ of the chemical, to prevent soil borne diseases. Weeds were removed by hand at interval of two weeks throughout the periods of the investigation. At maturity, harvesting was done by carefully uprooting the plant from the soil. Harvested pods were washed in running water to remove soil particles. The cleaned pods were manually detached from the plant and air-dried to $12 \%$ moisture for a period of seven days.

\section{Data collection}

At three weeks interval, morphological parameters such as plant height, number of leaves and number of primary branches were determined. The leaf area was recorded by measuring the length and breadth of twelve leaflets sampled from the base, middle and top of the plant in each experimental unit. These were summed together and multiplied by the total number of leaves and conversion factor of 0.65 (Lazarove, 1965). Thereafter, yield attributes such as number of matured pod per plant, number of seed per plant, seed weight per plant and 100seed weight were determined. Pod and seed yield were also measured in gram and converted to kilograms per hectare.

\section{Proximate composition}

The proximate composition in terms of moisture, ash, fibre, crude protein, crude fat and carbohydrate by difference were analysed using the methods of AOAC (2000).

\section{Data analysis}

Data collected were subjected to Analysis of Variance and Least Significant Difference (LSD) test at 5\% probability level was used to compare differences among the treatment means (Steel et al., 1997).

\section{Results}

\section{Growth response}

Results on plant height and number of primary branches as influenced by different land preparation methods at different growth periods are shown in Fig. 1. The plant height continued to rise with the age of the plant. The effect of planting methods on plant height at all sampling periods did not show statistical difference except at 12 weeks after planting (WAP). At all of the sampling periods, groundnut grown on raised beds showed the highest plant height, followed by ridges and flat surface. The number of primary branches at different growth period followed more or less a similar pattern as observed for the plant height, except that significant difference was not recorded in all the sampling periods (Fig. 1).

Number of leaves and leaf area of groundnut at different growth periods under the influence of different planting methods are presented in Fig. 2. Both parameters were observed to increase with the age. At 3 and 6 WAP, the effect of land preparation methods on both parameters was not significant. At 9 and 12 WAP significant differences in both number of leaves and leaf area were recorded. At these periods,

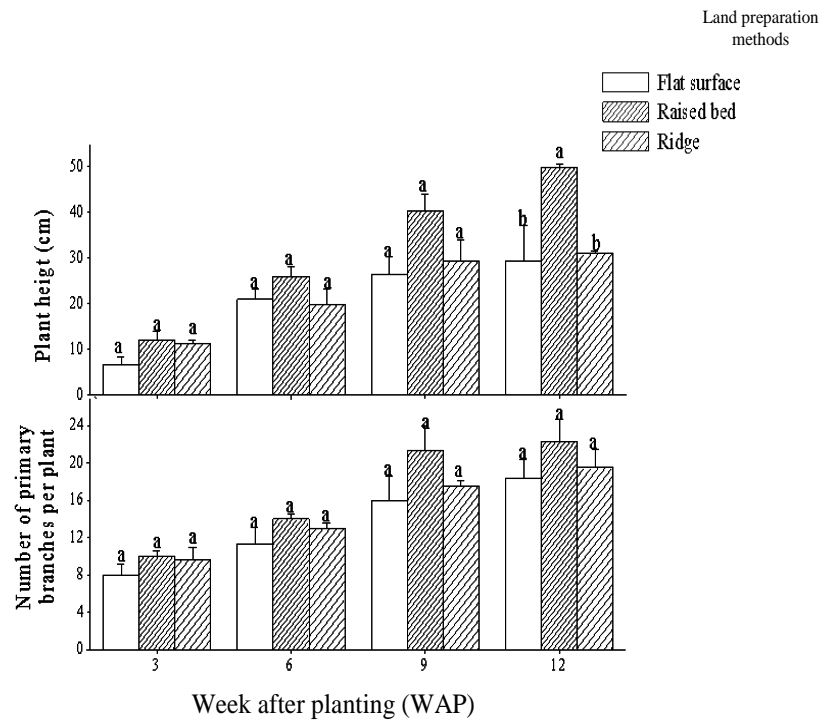

Fig. 1. Plant height and number of primary branches as affected by different preparation methods

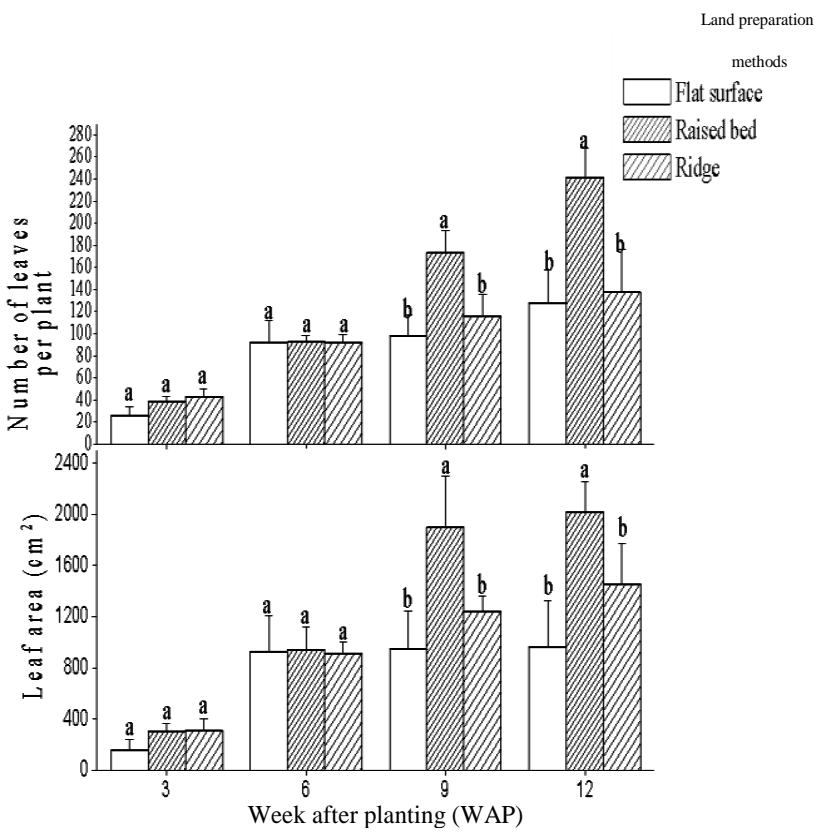

Fig. 2. Number of leaves and leaf area as affected by land preparation methods 
Table 1.Yield components and yield as influenced by different land preparation methods

\begin{tabular}{|c|c|c|c|c|c|c|}
\hline $\begin{array}{l}\text { Land } \\
\text { preparation } \\
\text { methods }\end{array}$ & $\begin{array}{c}\text { Number of } \\
\text { matured pod per } \\
\text { plant }\end{array}$ & $\begin{array}{c}\text { Number of seeds } \\
\text { per plant }\end{array}$ & $\begin{array}{l}\text { Seed weight per } \\
\text { plant }(\mathrm{g})\end{array}$ & $\begin{array}{c}100 \text { seed weight } \\
\text { (g) }\end{array}$ & $\begin{array}{l}\text { Pod yield } \\
\text { (kg/ha) }\end{array}$ & $\begin{array}{l}\text { Seed yield } \\
(\mathrm{kg} / \mathrm{ha})\end{array}$ \\
\hline Flat surface & $10.00 \pm 3.46^{\mathrm{c}}$ & $19.67 \pm 2.40^{b}$ & $10.41 \pm 1.31^{\mathrm{b}}$ & $39.63 \pm 2.92^{\mathrm{a}}$ & $992.50 \pm 80.65^{\mathrm{b}}$ & $679.79 \pm 55.07^{\mathrm{b}}$ \\
\hline Raised bed & $27.35 \pm 3.52^{\mathrm{a}}$ & $63.33 \pm 9.78^{\mathrm{a}}$ & $21.18 \pm 1.86^{\mathrm{a}}$ & $44.68 \pm 5.09^{\mathrm{a}}$ & $1731.00 \pm 1.81^{\mathrm{a}}$ & $1219.40 \pm 61.99^{a}$ \\
\hline Ridge & $11.33 \pm 4.48^{b}$ & $27.67 \pm 4.67^{b}$ & $12.41 \pm 1.85^{\mathrm{b}}$ & $39.67 \pm 2.92 \mathrm{a}$ & $1386.9 \pm 2.54^{\mathrm{a}}$ & $914.98 \pm 1.87^{\mathrm{a}}$ \\
\hline L.S.D 5\% & 12.96 & 16.06 & 5.69 & 11.75 & 626.32 & 397.89 \\
\hline CV $(\%)$ & 62.58 & 58.23 & 38.47 & 13.87 & 30.99 & 31.32 \\
\hline
\end{tabular}

Table 2. Seed quality as influenced by different land preparation methods

\begin{tabular}{|c|c|c|c|c|c|c|}
\hline $\begin{array}{l}\text { Land preparation } \\
\text { Methods }\end{array}$ & Moisture & Ash & Fibre & Protein & Fat & Carbohydrate \\
\hline \multicolumn{7}{|c|}{ 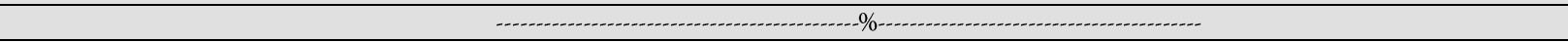 } \\
\hline Flat surface & $10.67 \pm 0.61^{\mathrm{a}}$ & $2.07 \pm 0.20^{c}$ & $4.97 \pm 0.05^{\mathrm{c}}$ & $23.84 \pm 0.14^{\mathrm{c}}$ & $48.86 \pm 0.47^{\mathrm{a}}$ & $9.59 \pm 0.19^{a}$ \\
\hline Raised bed & $11.00 \pm 0.71^{\mathrm{a}}$ & $2.38 \pm 0.33^{\mathrm{a}}$ & $9.95 \pm 0.19^{\mathrm{a}}$ & $26.51 \pm 0.20^{\mathrm{a}}$ & $44.17 \pm 0.37^{\mathrm{c}}$ & $5.89 \pm 0.14^{\mathrm{c}}$ \\
\hline Ridge & $11.30 \pm 0.88^{\mathrm{a}}$ & $2.25 \pm 0.33^{\mathrm{b}}$ & $7.76 \pm 0.15^{\mathrm{b}}$ & $25.03 \pm 0.15^{\mathrm{b}}$ & $45.17 \pm 0.36$ & $7.84 \pm 0.17^{\mathrm{b}}$ \\
\hline L.S.D. $5 \%$ & 2.06 & 0.56 & 0.11 & 1.35 & 0.48 & 0.48 \\
\hline CV $(\%)$ & 8.73 & 6.37 & 28.74 & 4.69 & 4.62 & 20.85 \\
\hline
\end{tabular}

Within column mean followed by the same letter are not significantly different at 0.05

number of leaves and leaf area production for groundnut planted on raised bed was significantly higher compared to those planted on flat surface and ridges. During most of the sampling periods, the number of leaves and the leaf area were lowest in groundnut grown on flat surface compared to all other land preparation methods (Fig. 2).

\section{Yield components and yield responses}

Aside from 100 seed weight, all other yield components were significantly influenced $(\mathrm{p} \leq 0.05)$ by different land preparation methods as shown in Table 1. Number of matured pods per plant, number of seeds per plant and seed weight per plant with respective values of $27.35 \pm 3.52,63.33 \pm 9.78,21.18 \pm 1.86 \mathrm{~g}$ were significantly highest in groundnut planted on raised beds and followed in decreasing order by ridges. Significantly lower values of these parameters were recorded from groundnut grown on flat surface (Table 1). The pod and seed yield followed the same trend as other yield components except that statistical differences were not recorded between groundnut planted on raised beds and ridges. However, pod and seed yield were higher in the former than the latter (Table 2).

\section{Seed quality}

The manner of land preparation had a significant effect $(\mathrm{p} \leq 0.05)$ on all the proximate composition except percentage moisture (Table 2). Regardless of the land preparation methods, the percentage moisture, ash, fibre crude protein, crude fat and carbohydrate had values that ranged between $11.30 \pm 0.88-10.67 \pm 0.61 \%, 2.38 \pm 0.33-2.07 \pm 0.20 \%, 4.97 \pm$ $0.05-9.95 \pm 0.19 \%, 23.84 \pm 0.14-26.51 \pm 0.20 \%, 44.17 \pm 0.37-$ $48.86 \pm 0.47 \%$ and $5.89 \pm 0.14-9.59 \pm 0.19 \%$, respectively (Table 2). Significantly higher ash $(2.38 \pm 0.33 \%)$, fibre $(9.95 \pm$ $0.19 \%)$ and crude protein $(26.51 \pm 0.20 \%)$ were recorded in seeds harvested from groundnut planted on raised beds when compared to other land preparation methods. Those obtained from ridges was also statistically higher than those obtained from flat surface. The crude fat and carbohydrate were however significantly higher in groundnut planted on flat surface with respective values of $48.86 \pm 0.47 \%$ and $9.59 \pm 0.19 \%$ compared to those obtained from ridges and raised beds (Table 2). Significantly lower values of fat and carbohydrate were recorded in groundnut on raised beds.

\section{Discussions}

In this investigation, it has been found that different land preparation methods (flat surface, raised beds and ridges) at early stages of crop growth may not have any significant effect on morphological parameters such as plant height, number of primary branches, leaf production and leaf area development. However, at later parts of the crop growth, groundnut planted on raised beds showed remarkable increase in all the aforementioned parameters compared to other planting methods. The enhanced growth in raised beds planting method may be attributed to more conducive soil conditions like proper aeration and adequate availability of moisture essential for emergence that resulted in more crop productivity (Bakht et al., 2011). Just like ridges, raised beds provided loose fertile soil with more aeration and moisture availability, and less mechanical compaction that permitted roots to grow profusely with more length compared to flat surface. This pattern of results is in agreement with the reports of Chassot and Richner (2002) who found that more bulk density or dense surface soil layer of flat surface is a limiting factor for root growth, resulting in less root length and concentrate the roots near soil surface, and this in consequence affect growth. Yield components aside from 100 seed weight in groundnut planted on raised beds showed marked increase compared to other land preparation methods. The reason for enhanced yield components is traceable to the fact that the raised beds provided loose soil surface for easier penetration of the pegs. Also, the shorter distance between the pegs arising from the lower branches and the soil surface is another plausible explanation for enhanced yield in raised beds method of land preparation. Another plausible explanation for enhanced yield in raised beds is uniform distance that is maintained between the pegs and the soil surface as the branches extend outward from the main stem. 
230

Mathukia et al. (2014) had reported alternate furrow and beds ( $\mathrm{a}$ form of raised bed) increased growth and yield components and pod yield of groundnut over flat beds, but remain at par with furrow and ridges. The low yield components recorded in ridges can be attributed to its conical structure where the pegs are to assume higher distance from the soil surface as the branches extend outward from the main stem. Therefore not all the pegs that were formed had the opportunity of penetrating the soil for pod formation. This could be the reason why farmers in Africa often practice earthing-up the branches with soil to decrease the distance between the pegs and soil surface for late formed pegs to enter the soil (Nigam et al., 2006). Among all the planting methods, the flat surface had the lowest yield components on account of its solid hard core which impeded peg penetration. Pod and seed yields were highest in raised beds compared to ridges and flat surface. This yield improvement could be attributed to increased yield components such as number of matured pod and seeds per plant. Similarly, the more conducive soil conditions crafted by this treatment for proper root development gave room for efficient accessibility of water and nutrients for enhanced pod formation and development. The significantly higher yield in ridge sown groundnut over flat surface was also the result of positive soil conditions provided by ridges resulting into better root system. This enables the plants to absorb more moisture and nutrients for enhanced leaf area development and pod production. Similar results have been reported in maize hybrids where ridges sowing supported better crop growth and productivity than flat bed sowing (Khan et al., 2012). Well developed root systems with the ability to explore greater soil volume has been recognized as an important adaptation of plants to ensure sufficient water and nutrient uptake (Horst $e t$ al., 2001). In this study improved method of land preparation like ridges and raised beds play a significant role to enhance crop productivity due to well developed root system It is interesting to note that different land preparation methods significantly influenced all the proximate compositions of the air dried seeds except moisture. The results of the moisture which ranged from $10.67 \pm 0.61$ to $11.30 \pm 4.48 \mathrm{did}$ not conform to other cultivars of groundnut. Musa et al. (2010) had reported moisture percent which ranged from 6.6 to $8.9 \%$. The variation could be attributed to varietal difference, agronomic practices as well as the number of days used to dry the seeds before subjecting the seeds to proximate analyses (Olayinka and Etejere, 2013). The ash, fibre and crude protein were significantly enhanced in raised beds, followed by ridges and flat surface. This is not unconnected to effective uptake and utilization of mineral resources available in the soil in raised beds than other land preparation methods. These results agreed with the findings of Olayinka and Etejere (2013), who found that effective weed control methods with reduced weed competition for available nutrients showed higher percentage of ash, fibre and crude protein than those of weedy check. The highest ash, fibre and crude protein recorded in raised beds is suggestive of the fact that groundnut raised under this practice will be a good source of food supplement in terms of providing essential minerals and dietary fibre for normal peristaltic of the intestinal tract. Diets low in crude fibre are undesirable as they could cause constipation and such diets have been associated with colon diseases, like piles appendicitis and cancer (Atasie et al., 2009). The results of the fat and carbohydrate were significantly enhanced in flat surface and lowest in raised beds and this is traceable to low nutrient uptake from the soil. Groundnut raised in such condition had no other alternative than to partition most of its resources towards building up fats and carbohydrates.

\section{Conclusions}

Land preparation methods influenced the growth, yield and proximate composition of groundnut seeds. However, raised beds methods showed the best growth and yield compared to other land preparation methods. Similarly, the use of raised beds had a positive influence on the ash, fibre and crude protein of the groundnut seeds and this implies that crop grown using raised beds as land preparation technique is good for human health and livestock feed.

\section{References}

Abdullah G, Hassan IA, Khan SA, Khan Ali H (2008). Impact of planting methods and herbicides on weed biomass and some agronomic traits of maize. Pak J Weed Sci Res 14:121-130.

AOAC (2000). Official Method of Analysis (17th Edition). Volume 1. Association of Official Analytical Chemists Inc, Maryland, USA.

Bakht J, Shafi M, Rehman H, Uddin R, Anwar S (2011). Effect of planting methods on growth, phenology and yield of maize varieties. Pakistan Journal of Botany 43:1629-1633.

Atasie VN, Akinhanmi TF, Ojiodu CC (2009). Proximate analysis and physico-chemical properties of groundnut (Arachis hypogaea L.) Pakistan Journal of Nutrition 8:194197.

Campos-Mondragón MG, Calderón Dela-Barca AM, Duran-Prado A Campos-Reyes LC, Oliart-Ros RM, Ortega-Garcia J, MedinaJuarez LA, Angulo O (2009). Nutritional compostition of new peanut (Arachis hypogaea L.) cultivars. Grasas y Aceites 60(2):161167.

Chassot A, Richner W (2002). Root characteristics and phosphorus uptake of maize seedlings in a bilayered soil. Agronomy Journal 94:118-127.

Khan MB, Yousaf F, Hussain M, Haq MW, Lee DJ, Farooq M (2012). Influence of planting methods on root development, crop productivity and water use efficiency in maize hybrids. Chilean Journal of Agricultural Research 72(4):556-563.

Govaerts B, Sayre KD, Deckers J (2004). Stable high yields with zero tillage and permanent bed planting. Field Crops Res 79:116-118.

Hamidu BM, Kuli SG, Mohammed I (2006). Profitablity analysis of groundnut (Arachis hypogaea L.). Processing among woman Enterprenuers in Bauchi Mertropolis. A paper presented at $20^{\text {th }}$ Annual National Conference of Farm Management Association of Nigeria, held at Forestry Reseach Insitute of Nigeria Federal College of Forestry Jos, Plateau State. 18 $8^{\text {th }}-21^{\text {st }}$ Sept 2006. 
Horst WJ, Kamh M, Jibrin JM, Chude VO (2001). Agronomic measures for increasing $\mathrm{P}$ availability to crops. Plant and Soil 237:211-223.

Lazarov R (1965). Coefficient for determining the leaf area in certain agricultural crops. Rast Nauki Sofia 2:27-37.

Liu MX, Yong QG (2008). Effects of ridge-furrow tillage on soil water and crop yield in Semi arid region. The $2^{\text {nd }}$ International Conference on 16-18 May, 2008.

Mathukia RK, Panara DM, Patel KC, Mathukia RR (2014). Response of Kharif groundnut (Arachis hypogaea) to land layouts, mulches and nutritional management. Innoriginal International Journal of Sciences 1(1):3-4.

Musa AK, Kalejaiye DM, Ismail LE, Oyerinde AA (2010). Proximate composition of selected groundnut varieties and their susceptibility to Trogoderma granarium Everts attack. Journal of Stored Products and Post Harvest Research 1(2):13-17.

Nigam SN, Aruna R, Giri DY, Rao GVR, Reddy AGS (2006). Obtaining sustainable higher groundnut yield: Principles and Practices of Cultivation. Information Bulletin No. 71. International Crops Research Institute for the Semi-Arid Tropics pp 18.

Obi JC, Ogunkunle AO, Meludi NT (2008). Effect of termite infestation on the faming system and characteristics of an endemic area in the Guinea savanna region of Nigeria. American Eurasian Journal of Scientifics Research 3(1):1-6.
Olayinka BU, Etejere EO (2013). Influence of weed management strategies on proximate composition of two varieties of groundnut (Arachis hypogaea L.). Annals Food Science and Technology 14(2):286-293.

Ortega AL, Mir EV, Rangel EE (2008). Nitrogen management and wheat genotype performance in a planting system on narrow raised beds. Cereal Res Commun 36:343-352.

Savage GP, Keenan JI (1994). The composition and nutritive value of groundnut Kernels. In: Smart J (Ed). The groundnut crop: Scientific basis of improvement, London: Chapman and Hall pp 173-213.

Steel RGD, Torrie JH, Deekey DA (1997). Principles and procedures of statistics: A biometrical approach. 3rd ed. McGraw Hill Book, New York, USA pp 400-428.

Suryawanshi MW, Jadhav GS, Jadhav PD, Jagtap PB (2008). Influence of land layouts and irrigation scheduled on yield and water-yield response function of groundnuts. Journal of Soil and Crops 18(11):112-116.

Wang F, Xuqing W, Sayre K (2004). Comparison of conventional, flood irrigated, flat planting with furrow irrigated, raised bed planting for winter wheat in China. Field Crops Res 87:35-42. 